\title{
Professional development shaping teacher agency and creative insubordination
}

\author{
Desenvolvimento profissional do professor \\ provocando a agência e a insubordinação criativa
}

Celi Espasandin Lopes ${ }^{1}$ • Beatriz Silva D’Ambrosio ${ }^{2}$

\begin{abstract}
The goal of this paper is to discuss the acts of creative insubordination of four mathematics teachers revealed in their narratives. The four teachers shared a common experience; they participated in a course entitled Teaching Mathematics in the Early Grades, which contributed to their professional development. Through the narratives, we identify how the course provoked teachers' agency and their acts of creative insubordination. The collaborative nature of the course, along with the reflection on practice, the group deliberations about implementing alternative teaching strategies, and the documentation of student learning, provided teachers with the confidence and self-efficacy necessary to defend the multiple dimensions of their practice and their acts of creative insubordination.
\end{abstract}

Keywords: Teacher education. Mathematics education. Creativity. Autobiographical narratives.

Resumo: Este artigo objetiva discutir os atos de insubordinação criativa revelados em narrativas de quatro professoras de matemática participantes de um curso de especialização intitulado Teaching Mathematics in the Early Grades, que contribuiu para o seu desenvolvimento profissional. O curso provocou agência e atos de insubordinação criativa por parte das professoras. A natureza colaborativa do curso, as reflexões e as deliberações sobre estratégias de ensino alternativas e registros de processos da aprendizagem proporcionaram confiança e autoeficácia necessárias para suas práticas e seus atos de insubordinação criativa. Palavras-chave: Formação de professores. Educação matemática. Criatividade. Narrativas autobiográficas.

\footnotetext{
${ }^{1}$ Universidade Cruzeiro do Sul, São Paulo, SP, Brasil. E-mail: <celi.espasandin.lopes@gmail.com>.

$2+$ In memoriam.
} 


\section{Introduction}

In the current climate of public policies for education that emphasize standardized testing of children and teachers, there is a sense of loss of professionalism and loss of autonomy among teachers. The policies place unwarranted stress on teachers and children. Yet, some teachers find ways to circumvent the policies and create a climate conducive to learning for their students. Teachers' strategies to alleviate the current demands of their profession and to work in ways that support their students, even when their actions are contrary to the mandates or culture of the school, are revealed by this study.

The goal of this paper is to discuss the acts of creative insubordination of four mathematics teachers revealed in their narratives. The narratives of the participating teachers pointed to a common experience that contributed to their professional development, which seems to have been responsible, at least in part, for the teachers' willingness to engage in acts of creative insubordination. This experience consisted in the participation in a 360-hour course entitled Teaching Mathematics in the Early Grades, at the Mathematics Institute of the State University of Campinas, between 2003 and 2004. The objective of the course was to examine how children learn mathematics in the early grades of elementary school. The teachers took the course of their own accord because they sought a better understanding of mathematical concepts and procedures. When asked about their investment in their own professional development, the four teachers highlighted this specialization course as crucial.

We believe that professional development is based on a certain self-education, in which teachers look for, decide, design and implement a training plan. It is through this quest that teachers improve their knowledge, skills and/or attitudes, embarking in a self-development process brought about by their own initiative. (LOPES, 2003).

The course Teaching Mathematics in the Early Grades was planned and grounded in the understanding that teachers produce knowledge during both formal classes and throughout their careers. In each class meeting, participating teachers were challenged to investigate their practice, create activities, and analyse their implementation. Through reflection and socialization with peers, teachers engaged in a movement of elaborating, perceiving and further understanding their professional identity.

This course employed a different assessment method; at the end of each discipline, the participants needed to present to the class the elaboration, development and analysis process of mathematical activities they had conducted with their students. In their narratives, the teachers reported that this fostered meaningful learning with their peers. This kind of evaluation is based on the principle that collaboration among teachers should be encouraged during teacher training activities. It also considered collaboration as a promoter of professional growth. Collaborative work was seen as a possibility for teachers to share their ideas, values and visions through the socialization of their thought process and practice. (LOPES, 2003).

In this study, we used autobiographical narratives as our data sources. The four teachers shared their professional life histories, recounting times when their beliefs led them to break the rules of the institution or counteract the expectations of their supervisors or parents, in favour of their students. In the methodology section, we will be more specific about the ways in which autobiographical narratives were generated. 
Our analysis is grounded in our view that understanding the professional development of teachers who are subversively responsible can guide teacher education, both continuing and initial, to empower teachers to participate in a movement to recover and regain the honour and dignity of the teaching profession.

\section{Theoretical framework and relevant literature}

The theoretical framework that informs this study lies in the intersection of two literature bases: creative insubordination, which has emerged and established itself outside of mathematics education, and teacher agency and professional identity, which has a tradition within mathematics education. In this section we bring these two literatures together in order to guide the analysis of our data.

\section{Creative insubordination}

Breaking rules for the benefit of those one serves, are called acts of "responsible subversion" in the nursing literature (HUTCHINSON, 1990). In the education literature, primarily in studies of school administrators, the preferred terminology is "creative insubordination" (MCPHERSON; CROWSON, 1993; HAYNES; LICATA, 1995). More recently, in the specific area of mathematics education, Gutiérrez (2013) describes teachers' creative insubordination as necessary to set in motion the political action of mathematics teachers. For Gutiérrez, in the current configuration of public policies that create oppressive environments for teachers and students, teachers should develop their political voice, resulting in acts of creative insubordination. From this perspective the political actions of a mathematics teacher would include taking a position in opposition to the standard curriculum, to evaluation practices, to rules and guidelines regarding the use of technology in the classroom, when any of these seem to be unfavourable to the learning of one's students.

\section{Professional identity and agency}

In spite of the numerous scholars who define identity (SACHS, 2001; SFARD; PRUZAK, 2005) or mathematical identity and agency (BOALER; GREENO, 2000; VAN ZOEST; BOHL, 2005) we have situated our discussion of identity and agency in the writings of Day (2004), Gutierrez (2013), and Passeggi and Cunha (2013).

In particular, for this study, we draw on the definition of professional identity of Day (2004), in which he considers that identity is formed in the mind, body and heart. Identities are an amalgam of personal biography, culture, social influence and institutional values, which can change according to one's function and working conditions (DAY, 2004) and, thus, evolve over time. According to Day, early career teachers adapt to the expectations and guidelines of their peers. Over time, teachers more actively engage in invention and originality, rather than reproduction and imitation of teaching practices. At this stage, they are working towards building their own identity. In this sense, each teacher is unique, and defines his/her practices based on 
personality traits, feelings, beliefs, and expectations. The professional identity of mathematics teachers is linked to their mathematical knowledge, their relationships with students, their role as educators and the connections between life within and outside of school.

Identity as described by Day (2004) also includes a political voice mentioned by Gutiérrez (2013). It is in this encounter of theories that we seek to understand the professional identity of teachers interviewed, outlining situations of life and profession that have led them to become stakeholders in the development of their autonomy and agency (PASSEGGI; CUNHA, 2013). For Passeggi and Cunha (2013, p. 46), agency implies "self-knowledge, self-esteem and self-regulatory capacity in determining one's actions". The notion of agency shapes the description of the teachers' decision-making process regarding not only their own paths towards professional development, but also their choices and decisions regarding classroom practices that are most beneficial for their students' learning of mathematics.

When teachers are mobilized to enhance student learning and invest in improving the conditions under which such learning occurs, they create and put into motion standards and procedures that are aligned with their professional identity. At times these attitudes are responsibly subversive, and result in acts of creative insubordination.

\section{Methodology}

As we considered teachers as protagonists in the construction of their identities, we chose to conduct a study through narratives, understanding, as do Clandinin and Connelly (2000), that narratives reveal how humans experience the world and assist in understanding how they characterize their human experiences. Since education is the construction and reconstruction of personal and social histories, narrative research allows for greater clarity about the phenomenon being investigated. For the authors, the narrative can be treated as a phenomenon that is being investigated and in this case, it can be a written or spoken product; or as a research methodology when it is used to build and analyse narrative phenomena. In this sense narratives can be used for different purposes, for example, to understand the development of teachers' professional identities.

Four teachers were interviewed and narratives written from their reflections of their professional life histories and their interpretations of their professional identities. The narratives were analysed with the goal of identifying acts of creative insubordination in their professional journey as mathematics educators. We were trying to understand what enables teachers to act on behalf of the best interest of their students in spite of policies that may not serve students well.

In this study, the narrative takes on the dimension of the phenomenon under investigation and the method of investigation: the data are the (auto) biographical reports, shared with the researchers through interactive dialogue. In regular meetings with the researchers, over anywhere from one to four hours of interactive dialogue, the teachers constructed their (auto) biographical narratives, sharing multiple dimensions of their professional development and professional lives. We probed teachers in order to construct their professional trajectories, starting with their experiences in teacher education and continuing throughout their professional lives as mathematics educators. We explored multiple dimensions of their growth as mathematics teachers and the development of their professional identities. It was our goal to 
map the actions of creative insubordination that they reported taking in order to assure the learning and development of their students.

Interviews that generate narratives are conversations, rather than formal interviews, which is why we refer to them as interactive dialogues. Each participant was asked to tell the researchers about her professional life history and was prompted for clarification or for greater details about the events as they were described in an effort to engage both interviewee and researchers in co-constructing the narratives (CLANDININ, 2013).

The conversations were transcribed and analysed by the researchers. The analysis was guided by the main research goal of identifying acts of creative insubordination revealed by the teachers as moments in which they broke rules or worked in opposition to policies during their teaching of mathematics. The multiple readings and interpretations, coupled with a validation of analysis substantiated by commonalities found in individual researcher interpretations, resulted in conjectures regarding teachers who dare to break rules in favour of the learning of their students. The detailed discussion of each interview, contrasting our interpretations and seeking common ground, enriched our understanding of the professional identity of teachers who reinvent their practice in order to take into account the needs of their students. We realize that each story told by us, is a second order interpretation of the facts, as we insert ourselves in our subjects' stories interpreting them through our own lenses that are shaped by our life histories, our views of the world, our beliefs, and our values.

Grounded in the work of Harkness (2009), our listening to the stories of our subjects was done within a believing framework, rather than listening with doubt, or doubting the truth of their narratives. In this sense, we understood their narratives as the construction of their reality, as they remembered it. We sought to understand their stories, seeking to situate their narratives in the context of their personal and professional lives. It was important to honour the complexity of each life and each professional journey as teachers described their trajectories in building their professional identities.

The analysis of the four narratives was grounded in teachers' personal interpretations regarding their attitudes of insubordination and in their perceptions of the construction of their professional identities. We were driven to listen to teachers and hear their voices as they reconstructed the events that framed their professional lives and exposed their professional identities. It is the analysis of the stories of the four teachers that we report here.

\section{Data analysis and findings}

\section{Introducing the four teachers}

The four teachers who provided the data for this analysis are Cristina, Isabella, Juliana and Clotilde. These pseudonyms were picked by each of our interviewees. In an effort to introduce the reader to these teachers, we briefly summarize their narratives highlighting some of the key aspects of their individual stories.

Cristina studied in a private school her whole life. Her parents and her schools were very rigid with her. She studied to be an elementary school teacher and had the opportunity to take a course from Paulo Freire. Upon completing her undergraduate studies she began teaching 
young children. To this day she teaches young children reading, writing and mathematics. She feels very successful in her profession. Throughout her career, she sought opportunities for professional development, by participating in courses, attending events, and attending lectures. She was a member of a research study-group regarding mathematical knowledge. She points to a course for practicing teachers offered at the university specifically for teachers of mathematics in the early grades as being instrumental in her views of how to work effectively with young children learning mathematics.

Isabella's undergraduate degree was as mathematics teacher and she immediately began teaching upon graduation. She believed that mathematical content knowledge was the cornerstone of teacher knowledge for success as a mathematics teacher, so she soon enrolled in a graduate course in pure mathematics at the university. Soon she became aware that the mathematical content knowledge alone was insufficient for successful teaching. This was a turning point for her, as she began searching for and participating in professional development experiences that would address several of her concerns about her students' learning of mathematics. In her third year teaching, she participated in a mathematics education course about mathematical modelling, with emphasis on the use of mathematical modelling as a teaching methodology. It was a course in teaching mathematics to young children that expanded her understanding of how children learn mathematics. Currently Isabella has over 20 years of teaching experience and feels confident in her teaching. She completed a masters' degree in Education and participates regularly in collaborative research study-groups that have resulted in publications in which she describes her teaching practices. These experiences have increased her self-confidence and self-efficacy regarding her professional activities.

Juliana always wanted to be a mathematics teacher and pursued this career throughout college. She described the experiences in classrooms during her teacher education program, as the most influential in developing her enthusiasm for teaching. Upon completing her undergraduate preparation for teaching, she took a position teaching children in the sixth year of basic education in the public school system. Her greatest difficulties appeared as she struggled to help children who grappled with the basic operations. Her preparation did not prepare her to provide the support needed to remediate children's learning from earlier years. She knew that she needed to supplement her education with knowledge about how children learn mathematics, extending her knowledge beyond mathematical content. Thus she enrolled in a graduate course about the teaching of mathematics to young children. This course encouraged her to take others that would expand her knowledge of mathematics learning. Her participation in a research study group finally led to her enrolment in a master's degree program. Early in her career she taught older students, who were returning to school to finish their education, but in the last ten years she has been teaching the last years of secondary education in rural areas.

Clotilde remembered admiring her mother's dedication to teaching and this led her to aspire to be a teacher. Ever since her early education she loved mathematics and logical challenges. At 15 years of age, she began working in a pre-school, as she prepared to be a teacher in a teacher education program at high-school level (sometimes known as normal school). Her college education was in the area of business administration, since her intent was to manage the family business. She worked in the business world for 5 years before returning to the classroom. Her need to know more about how children learn led her to enrol in another degree program, in psychopedagogy. She and a colleague created a collaborative research study group 
about mathematics teaching and learning. She also attended the course Teaching Mathematics in the Early Grades. She reported that the course was a key element in her professional development because the theory was tied to practice. What was discussed in the course had to be tried out in the classroom and data about the implementation brought back to class for discussion.

The journeys of these four teachers are all similar as to their personal investment in their professional development emerging from a dissatisfaction with their initial preparation. As they reflected on the difficulties of interacting with their students, they became aware of the fragility of their practice as they struggled to reach reluctant mathematical learners. Their continuous movement in seeking further professional development to overcome their challenges with learners lead them to acquire not only knowledge about teaching and learning, but also autonomy and confidence in redefining their practice.

The four teachers participated in the course Teaching Mathematics in the Early Grades in different phases of their careers. It is the impact of that course in developing their agency and creative insubordination that is the focus of this analysis.

\section{Impact of course Teaching Mathematics in the Early Grades}

From the four teachers' narratives, we extracted instances in which they described their experiences in this particular course and attributed to the course the power of pushing their thinking and building their agency, as they planned for and implemented acts of creative insubordination.

Isabella and Juliana took the course sensing the need to fill a gap in their preparation. Isabella reports that the course "deviated from existing paradigms of professional development." Instead of lectures, and a focus on mathematics, the course focused on how children learned mathematics. This was contrary to her previous experiences in professional development, where doing higher-level mathematics was the focus. Having taught for a few years, Isabella had become aware that the mathematics courses were not helping her redefine her practice in order to be more successful with struggling students, leading her to enrol in this course. As both Isabella and Juliana engaged in constructing their narratives it became evident that they were self-aware of the reasons leading to their search for professional development. They were clear in articulating their need for self-actualization as professionals, thus characterizing an important component of their professional identities.

Similarly we notice in Clotilde's narrative a personal commitment to her professional development. Clotilde described the experience in the course as one in which she came to realize the relationship of theory and practice. In her words, "I came to discover that I didn't have to be tied to the research to then shape my practice, on the contrary, the theory exists to support and explain what we do." It was with this perspective that Clotilde reflected on her practice and justified her actions. Encouraged by the discussions that occurred during the course, Clotilde deviated from the curriculum adopted in her school, and approached the teaching of mathematical topics by engaging her children in investigative projects that connected learning mathematics to a real world context. She stated that in the course she did not learn how to teach particular topics, but rather how to support students to construct meaning for the topics as they encountered opportunities to use the mathematical content to make sense of the world around them. 
Her views of assessment also reveal an attitude of insubordination. She described having to document student learning in order to convey the richness of what they could do. Aware that student knowledge is not captured by a test, she developed alternative ways of documenting her students' understanding of mathematics.

Juliana described her experiences in the course, in similar terms to those used by Clotilde. She reflected on the importance of the group of colleagues to discuss and critique each others' practices. The "intent in the groups is to discuss and collaboratively push beyond what we each know." When questioned about why teachers don't establish these study groups within their schools, in order to sustain the continued reflective practice needed for professional growth, she described colleagues feeling threatened by the exposure in the process of dialogue and reflection. In her words, "often the profession of teaching becomes very solitary." In her experience she overcame the loneliness with the participation in the course. Seeking the support of colleagues outside her school provided the affirmation that her practice was valuable and her thinking worthy of sharing with others.

Juliana too, holds views of assessment that differ from the norm. She understands the work of assessment to be a continuous process of observation of students as they work on tasks, projects, and activities. She also breached institutional rules as she involved students in deciding on, collecting and providing her with evidence of their understanding.

Isabella, also found her practice to be contrary to the norms of the schools in which she taught. Particularly, when she took the students outside of the classroom in order to collect data and explore problems in the real world. The courage to pursue these explorations beyond the constraints of the classroom emerged from her participation in the course. She also explained how the course drew her focus towards planning instruction based on what she heard from the children. While she confessed to having been afraid of following the lead of the children, since their questions could lead down paths she did not have the confidence to follow, she soon realized that by having the children's questions drive instruction, she became a co-investigator with them and collaboratively they worked towards the mutual construction of knowledge. Of course, by pursuing questions raised by the children, the standard curriculum became irrelevant and uninteresting. By choice, Isabella deviated from the school's curriculum and the children's inquiries drove the instructional process in her classroom.

Similar acts of insubordination were inspired in Cristina. She described a project developed with her 7 year-old children around toys and games. Upon reading a piece of children's literature that juxtaposed the access to different types and quantities of toys by children of different socio-economic backgrounds, her class began asking many questions about poor children's access to toys, games, and playtime. Their question - "Why are there many children who can't play?" - led to an exploration of socio-cultural issues related to childhood labour, when children work to participate in the economic survival of the family. The children, in an act of solidarity, proposed making toys for those less fortunate than them. The mathematics of the second grade was explored in the context of this investigation about access to toys. Cristina's creative insubordination, of developing investigations based on the inquiries of the children, led to an elaborate interdisciplinary unit, that explored issues that would permit the children to reflect on and begin the task of making sense of the extremely complex reality of inequities in the world around them. 
For all four teachers the experience during the course Teaching Mathematics in the Early Grades greatly contributed to their professional development, as it afforded an opportunity to consider alternatives to a more traditional approach to curriculum. By collaboratively building opportunities for teachers to discuss, plan, implement, and reflect on inquiry-based lessons the group became self-sustaining and self-regulating. Participating teachers found complacency in the members of the group, thus feeling encouraged to stretch their thinking beyond their comfort zone in order to explore teaching strategies that broke away from the norms of the standard and traditional classroom experiences.

\section{Conclusions}

All four teachers in this report participated in a specialization course, which contributed significantly to their professional development. One of the objectives of the course was to encourage teachers to see themselves as builders of knowledge. In their narratives, the teachers revealed a construction of professional knowledge that allowed them to reconstitute their professional identities and, thus, develop and nurture the agency necessary for acts of creative insubordination. The new elements of their identities, such as confidence and self-assurance, encouraged them to step outside of the traditional norms related to the teaching of mathematics expected of them in their schools. In exploring their professional life histories, through their autobiographical narratives, composed through a process of interactive dialogues, teachers' personal reports attributed great significance to the course and its impact on their identities as teachers, i.e. the values and beliefs that drive their decision-making and actions in teaching.

Through the course the teachers participated and collaborated in the design of alternative perspectives regarding the teaching of mathematics resulting in creative enactments of modified professional practices. These practices were backed by the documentation of student learning, the reflective deliberation by the members of the group, and the nuanced description by each teacher of the details of the implementation. With this rich background of planning, design, and implementation, backed by data that documented student engagement, motivation and learning teachers felt empowered to incorporate these practices as an integral part of their professional identities. The characteristics of the course, with the documented evidence of impact on teachers' identity development, promoted the constitution of teachers who are responsibly subversive.

In each case, the four teachers, affirmed that after the experience they could teach in no other way. Teaching with projects and investigations had become a characteristic of their professional selves. The teachers' enhanced confidence and efficacy, assured them of agency as they made decisions to act subversively as they created what they knew to be the best possible experience for their students. Their acts of creative insubordination assured meaningful experiences for the children.

Creative insubordination is the culmination of teacher autonomy. One cannot have rules and/or recommendations that lead to insubordination. Being a subversively responsible professional stems from an peculiarly built professional identity. In this study, the narratives of the teachers show that a continuous development process, which remains linked to constant reflection about practice is what enables us to be creatively insubordinate. 
In the current stressful climate of schools, where teachers are not included in the design of curriculum that is often referred to as "teacher proof", in the evaluation of students through standardized tests, and in the notion of "one-size-fits all" education for children. Such teachers found agency as they reclaimed their classrooms and acted according to their professional ethics, making decisions about teaching and learning that they deemed good for their students.

\section{References}

BOALER, J.; GREENO, J. G. Identity, agency, and knowing in mathematics worlds. In: . (Ed.). Multiple perspectives on mathematics teaching and learning. Westport: Ablex Publishing, 2000. p. 171-200.

CLANDININ, D. J. Engaging in narrative inquiry. Walnut Creek: Left Coast Press, 2013.

CLANDININ, D. J.; CONNELLY, F. M. Narrative inquiry: experience and story in qualitative research. San Francisco: Jossey-Bass, 2000.

DAY, C. A passion for teaching. New York: Routledge Falmer, 2004.

GUTIÉRREZ, R. Mathematics teachers using creative insubordination to advocate for student understanding and robust mathematical identities. In: MARTINEZ, M. V.; CASTRO SUPERFINE, A. (Ed.). Proceedings: thirty-fifth Annual Meeting of the North American Chapter of the International Group for the Psychology of Mathematics Education. Chicago: University of Illinois at Chicago, 2013. p. 1248-1251. Retrieved from: < http:/ /www.pmena. org/pmenaproceedings/PMENA\%2035\%202013\%20Proceedings.pdf > . Last accessed: 6 oct. 2016.

HARKNESS, S. Social constructivism and the believing game: a mathematics teacher's practice and its implications. Educational Studies in Mathematics, New York, v. 70, n. 3, p. 243-258, 2009.

HAYNES, E.; LICATA, J. W. Creative insubordination of school principals and the legitimacy of the justifiable. Journal of Educational Administration, Bingley, v. 33, n. 4, p. 21-35, 1995.

HUTCHINSON, S. A. Responsible subversion: a study of rule-bending among nurses.

Scholarly Inquiry for Nursing Practice An International Journal, New York, v. 4, n. 1, p. 3-17, 1990.

LOPES, C. E. O conhecimento profissional dos professores e suas relações com estatística e probabilidade na educação infantil. 2003. 290 f. Tese (Doutorado) Faculdade de Educação, Universidade Estadual de Campinas, Campinas, 2003.

MCPHERSON, R. B.; CROWSON, R. L. The principal as mini-superintendent under Chicago school reform. Chicago: University of Illinois at Chicago, 1993. (Report, 143). Retrieved from: <http://eric.ed.gov/?id=ED373432>. Last accessed: 6 oct. 2016. 
PASSEGGI, M. C.; CUNHA, L. M. Narrativas autobiográficas: a imersão no processo de autoria. In: VICENTINI, P. P.; SOUZA, E. C.; PASSEGGI, M. C. (Ed.). Pesquisa (auto) biográfica: questões de ensino e formação. Curitiba: CRV, 2013. p. 43-57.

SACHS, J. Teacher professional identity: competing discourses, competing outcomes. Journal of Education Policy, Montgomery, v. 16, n. 2, p. 149-161, 2001.

SFARD, A.; PRUSAK, A. Telling identities: in search of an analytic tool for investigating learning as a culturally shaped activity. Educational Researcher, Thousand Oaks, v. 34, n. 4, p. 14-22, 2005.

VAN ZOEST, L. R.; BOHL, J. V. Mathematics teacher identity: a framework for understanding secondary school mathematics teachers' learning through practice. Teacher Development, Montgomery, v. 9, n. 3, p. 315-345, 2005. 